\title{
PENGARUH BIMBINGAN KELOMPOK DENGAN TEKHNIK PEER GROUP DALAM MENINGKATKAN INTENSITAS BELAJAR KELOMPOK SISWA SD NEGERI TAMANSARI II YOGYAKARTA TAHUN PELAJARAN 2016/2017
}

\author{
Yulian Agus Suminar \\ Program Studi Bimbingan dan Konseling \\ Fakultas Keguruan dan Ilmu Pendidikan \\ Universitas PGRI Yogyakarta \\ E-mail: yulian45_upy@yahoo.com
}

\begin{abstract}
Abstrak
Tujuan dari penelitian ini adalah untuk melihat seberapa besar pengaruh bimbingan kelompk dengan teknik peer group dalam meningkatkan intensitas belajar kelompok siswa SD Negeri Tamansari II. Penelitian ini merupakan model penelitian eksperimen. Adapun analisis data dalam penelitian ini meenggunakan rumus wilcoxon. Hasil dari penelitian ini adalah bimbingan kelompok dengan teknik peer group efektif meningkatkan intensitas belajar kelompok siswa SD Negeri Tamansari II. Hal ini terbukti dengan asymp sig (2-tailed) untuk diuji 2 sisi adalah 0,000, maka probabilitas menjadi $0,000 / 2=0,000$.
\end{abstract}

Kata kunci: bimbingan kelompok, peer group, intensitas belajar kelompok

\begin{abstract}
The purpose of this study is to see how much influence the guidance kelompk with peer group techniques in increasing the intensity of learning groups of elementary students Tamansari II State. This research is an experimental research model. The data analysis in this study using wilcoxon formula. The result of this research is group guidance with peer group technique to effectively increase the intensity of study group of elementary students of Tamansari II State Elementary School. This is proven by asymp sig (2-tailed) for 2 sided test is 0,000, then the probability becomes 0,000/2=0,000.

Keywords: group guidance, peer group, group learning intensity
\end{abstract}

\section{Info Artikel}

Diterima Mei 2017, disetujui Juni 2017, diterbitkan Juni 2017 


\section{PENDAHULUAN}

Pendidikan sebagai salah satu usaha yang berpengaruh pada kualitas hidup manusia. Pendidikan melibatkan berbagai komponen yang sangat penting antara lain lingkungan keluarga, lingkungan masyarakat dan lingkungan sekolah. Siswa yang seharusnya dapat berinteraksi dengan teman dan berdiskusi tentang kesulitan terhadap mata pelajaran tertentu akan terhambat dengan adanya larang yang diberikan oleh orang tua. Kondisi demikian akan berpengaruh pada proses belajar siswa yang cenderung akan terbiasa belajar sendiri di rumah tanpa pernah mengetahui cara belajar yang lain. Lingkungan sekolah menyediakan fasilitas penunjang belajar siswa mulai dari buku pelajaran, guru pengajar hingga fasilitas fisik lain. Sekolah berusaha mengembangkan dan mengoptimalkan kemampuan siswa dengan melibatkan seluruh warga sekolah antara lain adalah guru. Guru memiliki andil besar untuk menentukan hasil belajar siswa. Kebebasan belajar yang diberikan oleh guru membuat siswa lebih mengetahui tentang berbagai hal. Media internet dapat memudahkan siswa untuk menyelesaikan tugas dari guru. Berbagai informasi serta pengetahuan yang bermaanfaat bagi siswa telah tersedia. Pengetahuan yang tersedia di internet bukan hanya pengetahuan yang berhubungan dengan pelajaran sekolah melainkan juga masalahmasalah yang sedang diperbincangkan masyarakat. Dengan demikian setiap informasi yang ada dapat menambah wawasan dan dapat dijadikan bahan diskusi dalam kelompok. Siswa yang dapat mengatasi faktor yang mempengaruhi belajar maka akan berhasil dalam belajar. Namun, sebagian siswa belum dapat mencapai hasil yang maksimal salah salah satunya karena pengetahuan tentang cara belajar yang kurang.

Salah satu penelitian yang dilakukan di SMP Negeri 1 Kemusu Boyolali kelas VIII tahun pelajaran 2008/2009, dapat disimpulkan bahwa: "ada perbedaan prestasi belajar yang signifikan dalam bidang studi IPS antara siswa yang belajar kelompok dengan siswa yang belajar tidak kelompok". Hal tersebut mengindikasikan bahwa belajar secara kelompok dapat menghasilkan prestasi belajar yang lebih baik dibandingkan dengan cara belajar tidak kelompok. Dalam belajar kelompok tersebut siswa dilatih untuk mengemukakan pendapat, menghormati pendapat orang lain, berhubungan atau berinteraksi dengan orang lain, dan menerima keputusan yang telah disepakati kelompok. Belajar kelompok bermanfaat di bidang pelajaran maupun di luar pelajaran. Dibidang pelajaran untuk memperjelas pelajaran bagi anggota kelompok yang belum jelas dan yang sudah jelas akan semakin jelas. Namun, kelompok yang dimiliki siswa cenderung bukan kelompok belajar misal, geng sekolah yang sebagian besar tujuaannya hanya 
untuk berkumpul tanpa ada topik pembicaraan yang bermanfaat. Ini berbeda dengan belajar kelompok yang akan ada pembahasan masalah tentang kesulitan belajar yang akan dipecahkan secara berasam-sama.

Bagian penting dalam belajar kelompok ialah intensitas belajar kelompok. Belajar kelompok bukan hanya dilihat dari lamanya kegiatan tersebut tapi juga kualitas dan kuantitas. Kualitas belajar kelompok dapat dilihat dari pembahasan mengenai mata pelajaran yang sebagian besar anggota kelompok belum jelas, proses dalam belajar kelompok tersebut, serta hubungan yang terjalin antar anggota. Siswa merupakan pelaku utama dan penentu kesuksesan intensitas belajar kelompok. Masa remaja yang identik dengan masa mencari jati diri membuat siswa mudah terpengaruh oleh berbagai kelompok yang ada di masyarakat dan sekolah. Hal tersebut secara langsung maupun tidak langsung juga akan berakibat pada intensitas belajar kelompok siswa. Belajar kelompok pada umumnya terjadi atas ketertarikan dan aktivitas bersama. Hubungan persahabat dan hubungan kelompok teman sebaya (peer group) yang ada dalam belajar kelompok bersifat timbal balik, saling membantu, memiliki persamaan kebutuhan dan tujuan.

Usaha yang dilakukan dalam rangka meningkatkan intensitas belajar kelompok tersebut ialah dengan mengoptimalisasikan layanan bimbingan dan konseling kepada siswa. Salah satu bentuk kegiatan dalam penerapan layanan bimbingan kelompok dengan teknik peer group (kelompok teman sebaya). Persamaan yang dimiliki dalam kelompok tersebut akan mendorong siswa untuk lebih tertarik dan selalu mengikuti kegiatan yang dilakukan oleh teman kelompok dan akan timbul kenyaman antar siswa dikarenakan adanya persamaan usia maupun tujuan yang ingin dicapai. Dengan peer group tersebut juga akan muncul interaksi dalam belajar kelompok yang akan membantu siswa untuk lebih terbuka menerima apa yang disepakati oleh kelompok tersebut. Dalam peer group tersebut akan timbul keleluasaan antar teman sebayanya dalam memecahkan suatu permasalahan antar anggota kelompok belajar dengan menyatukan berbagai jawaban atau pendapat siswa melalui pemikiran-pemikiran, pengetahuan, pergaulan, dan gagasangagasan dalam meningkatkan intensitas belajar kelompok.

\section{KAJIAN TEORI}

\section{Bimbingan Kelompok}

Bimbingan kelompok menurut Asmani (2010: 115) adalah, layanan bimbingan dan konseling yang memungkinkan sejumlah peserta didik (klien), secara bersama-sama, melalui dinamika kelompok, memperoleh bahan-bahan dari narasumber tertentu (terutama dari guru pembimbing), membahas secara bersama-sama pokok bahasan (topik) tertentu yang 
berguna untuk menunjang pemahaman dan kehidupan mereka sehari-hari, dan atau untuk pengembangan kemampuan sosial, baik sebagai individu maupun sebagai pelajar.

Sementara itu, Wibowo (2005: 17) menjelaskan bahwa bimbingan kelompok merupakan suatu kegiatan kelompok yang di dalamnya pemimpin kelompok menyediakan berbagai informasi bagi anggota kelompok serta mengarahkan diskusi agar anggota kelompok memiliki sifat sosial dan dapat mencapai tujuan bersama. Lebih lanjut dapat dijelaskan bahwa di dalam bimbingan kelompok lebih diarahkan pada masalah-masalah yang bersifat sosial sehingga anggota kelompok/individu yang tergabung dalam layanan bimbingan kelompok lebih memiliki jiwa sosial.

Selanjutnya Sukardi (2008: 64) mengemukakan bahwa layanan bimbingan kelompok yaitu layanan yang memungkinkan sejumlah peserta didik secara bersama-sama memperoleh berbagai bahan dari konselor yang berguna untuk menunjang kehidupan sehari-hari serta berguna untuk pengambilan keputusan. Pendapat tersebut menjelaskan bahwa di dalam bimbingan kelompok agar individu dapat mengambil sebuah keputusan maka diperlukan sebuah dinamika kelompok. Dinamika kelompok merupakan proses berjalannya kegiatan di dalam sebuah kelompok yakni tingkah laku individu satu akan mempengaruhi individu yang lain dalam satu kelompok sehingga keberhasilan kegiatan dalam kelompok dapat terlihat melalui dinamika kelompok.

Ahli lain, Natawidjaja (2009: 6) mengemukakan bahwa, bimbingan dan konseling kelompok adalah pelayanan bimbingan yang memanfaatkan suasana interaksi atau komunikasi kelompok, antara seorang konselor dengan kelompok konseli. Pendapat tersebut menjelaskan bahwa dalam pelaksanaan bimbingan kelompok diperlukan suasana interaksi antara konselor dengan kelompok konseli. Interaksi yang dimaksud bertujuan agar diperoleh dinamika kelompok yang mengacu pada pendapat beberapa ahli di atas maka dapat diketahui bahwa bimbingan kelompok adalah layanan bimbingan yang dilaksanakan melalui terhadap beberapa individu (konseli) sebagai anggota kelompok untuk membahas suatu permasalahan melalui sebuah dinamika kelompok agar anggota dapat memahami diri serta mengembangkan kemampuan sosial dalam berhubungan dengan orang lain secara tepat. Dalam bimbingan kelompok, dinamika kelompok merupakan sebuah unsur yang penting, sehingga apabila di dalam bimbingan kelompok tidak terdapat dinamika kelompok maka pelaksanaan bimbingan tidak akan efektif.

Berdasarkan pendapat beberapa ahli tersebut maka dapat dikemukakan bahwa tujuan pelaksanaan bimbingan kelompok adalah sebagai berikut : 
a. Mengembangkan kemampuan individu dalam berkomunikasi

b. Mengembangkan kemampuan individu dalam bersosialisasi

c. Meningkatkan kerjasama antar individu dalam kelompok

d. Mengembangakn pemahaman diri serta pemahaman terhadap orang lain

\section{Tekhnik Peer group}

Menurut Santoso (2006: 77) "Peer group merupakan kelompok teman sebaya yang sukses di mana siswa dapat berinteraksi". Ini artinya bahwa dalam peer group siswa dituntut untuk saling berhubungan dengan teman sebayannya. Dalam peer group akan ada kesamaan satu dengan yang lain, misalnya di bidang usia, kebutuhan, masalah dan tujuan yang akan memperkuat kelompok tersebut. Peer group yang dibentuk tidak dipentingkan adanya struktur organisasi, namun antara anggota kelompok satu dengan anggota kelompok yang lain dapat merasakan adanya tanggung jawab atas keberhasilan dan kegagalan kelompoknya. Intensitas belajar kelompok yang meningkat akan berpengaruh pula dengan meningkatnya interaksi siswa dengan teman sebayannya karena mereka memiliki tujuan yang sama yaitu dalam memecahkan masalah belajar yang dihadapi.
Tujuan peer group yang yaitu sebagai alat pengontrol tingkah laku dalam hubungan dengan orang lain serta sebagai sarana pengembangan kemampuan seseorang. Dalam penggunaan peer group ini bertujuan untuk membahas masalah-masalah tentang kesulitan belajar yang dihadapi oleh anggota dalam kelompok belajar itu sendiri.

Menurut Santoso (2006: 81) adapun ciri-ciri peer group antara lain:

a. Peer group tidak mempunyai struktur organisasi yang jelas karena terbentuk secara spontan. Setiap anggota peer memiliki kedudukan dan fungsi yang sama namun, ada satu orang yang disegani dan kemudian dijadikan pemimpin.

b. Peer group bersifat sementara karena tidak adanya struktur organisasi yang jelas dan keadaan yang dapat memisahkan anggota kelompok. Sehingga mutu hubungan yang bersifat sementara itu merupakan hal yang terpenting.

c. Peer group mengajarkan individu tentang kebudayaan yang luas. Misalnya peer group yang terjadi di sekolah, mereka umumnnya terdiri dari individu yang berdedabeda. Lalu mereka memasukkannya dalam kelompok sebaya sehingga mereka saling belajar secara tidak langsung tentang kebiasaan itu dan dipilih yang sesuai dengan kelompok, kemudian dijadikan kebiasaan kelompok. 
d. Anggota peer group adalah individu yang sebaya yang memiliki keinginan, tujuan dan kebutuhan yang sama. Misalnya, anak-anak usia SMP dan atau SMA.

\section{Intensitas Belajar Kelompok}

Belajar kelompok itu sendiri ialah belajar yang dilakukan secara berkelompok. Dalam hal ini yang dimaksud dengan kelompok itu sendiri menurut Fiedler (Walgito, 2008: 110) “ kelompok adalah sekumpulan individu yang mempunyai kesamaan, saling berdekatan, dan terlibat dalam suatu tugas bersama dalam mencapai tujuan bersama”. Dalam belajar yang dilakukan dengan berkelompok dapat diartikan sebagai suatu perubahan yang dilakukan secara bersama mencakup ranah efeksi, psikomotorik, kognitif yang relatif bersifat tetap untuk mencapai tujuan bersama.

Menurut Walgito (1995:104) manfaat belajar kelompok adalah sebagai berikut :

a. Membiasakan anak untuk bergaul dengan teman-temannya, bagaimana mengemukakan pendapatnya dan menerima pendapat dari teman lain.

b. Dengan belajar secara berkelompok turut pula merealisasikan tujuan pendidikan dan pengajaran.

c. Untuk belajar mengatasi kesulitankesulitan, teruatam dalam pelajaran secara bersama-sama. d. Belajar hidup bersama agar nantinya tidak canggung didalam masyarakat yang lebih luas.

e. Memupuk rasa kegotong royongan yang merupakan sifat bangsa Indonesia.

Menurut Kartono (2000: 233) "intensitas ialah besarnya atau kekuatan suatu tingkah laku, untuk merangsang salah satu indera, ukuran fisik dari atau data indera". Sedangkan menurut Suyitno (1991: 9) "intensitas sebagai kualitas suatu kondisi atau derajat kualitas, atau kualitas dari suatu pengalaman indera, yaitu ukuran kuantitif tentang kekuatan atau derajat suatu kekuatan". Dalam intensitas belajar kelompok seseorang melakukan suatu tindakan yang akan membuat perubahan pada dirinya maupun orang lain. Tindakan tersebut menggunakan dan memaksimalkan kemampuan yang dimiliki oleh masing-masing individu.

Kemampuan yang dimaksud ialah kemampuan setiap indera dalam diri individu. Sehingga intensitas itu sendiri merupakan derajat kualitas tingkah laku seseorang dalam melakukan suatu tindakan. Dengan demikian berdasarkan pada pengertian belajar kelompok yang telah diuraikan sebelumnya maka intensitas belajar kelompok adalah derajat kualitas dari sekumpulan orang dalam melakukan suatu perubahan yang menyangkut afeksi, psikomotorik dan kognitif melalui pengalaman dan latihan yang relatif bersifat tetap untuk mencapai tujuan bersama. Dengan berbagai 
pertimbangan tentang belajar serta pemilihan belajar kelompok maka dalam penelitian ini akan menitik beratkan pada intensitas belajar kelompok.

\section{METODE PENELITIAN \\ Pendekatan Penelitian}

Penelitian ini menggunakan pendekatan kuantitatif dengan jenis penelitian korelasional yaitu bertujuan untuk mendeteksi sejauh mana variasivariasi pada suatu faktor yang berkaitan dengan variasi-variasi pada satu atau lebih faktor lain berdasrkan koefisien korelasi. Pada dasarnya penelitian kuantitatif dilakukan pada penelitian inferensial (dalam rangka pengujian hipotesis) dan menyandarkan kesimpulan hasilnya pada suatu probabilitas kesalahan penolakan hipotesis nihil. Dengan metode kuantitatif akan diperoleh signifikansi perbedaan kelompok atau sigifikasi hubungan variabel yang diteliti.

\section{Tempat dan Waktu Penelitian}

Penelitian ini akan di laksanakan di SD Negeri Tamansari II Yogyakarta. Pelaksanaan penelitian diperkiraan selama 3 (tiga) bulan sejak Januari tahun 2017 sampai Maret tahun 2017.

\section{Populasi dan Sampel}

Populasi dalam penelitian ini adalah siswa SD Negeri Tamansari II Yogyakarta. Penelitian ini akan menggunakan Proportionate Stratified
Random Sampling yaitu pengambilan sampel dari populasi dilakukan secara acak dan populasi mempunyai anggota/unsur yang tidak homogen dan berstrata secara proporsional. Apabila subyeknya kurang dari 100, maka lebih baik diambil semua sehingga penelitiannya merupakan penelitian populasi. Jika jumlahnya subyeknya besar dapat diambil antara $10-15 \%$ atau $20-25 \%$ atau lebih. Penentuan jumlah anggota sampel dalam penelitian ini yaitu dengan mengambil $20 \%$ dari anggota populasi. Setelah menghitung jumlah anggota sampel dengan mengambil $20 \%$ dari anggota populasi maka, dapat diketahui sampel dalam penelitian ini berjumlah 30 siswa.

\section{Variabel Penelitian}

Dalam peneltian ini terdapat dua variabel, diantaranya, a) variabel bebas dalam penelitian ini adalah bimbingan kelompok dengan tekhnik peer group, b) variabel terikat dalam penelitian ini adalah intensitas belajar kelompok.

\section{Instrumen Pengumpulan Data}

Instrumen pengumpulan data yang peneliti gunakan yaitu skala psikologis. Skala psikologis berisi lembar evaluasi yang ditujukan kepada siswa untuk mengetahui keadaan intensitas belajar kelompok siswa dan menguji keefektifan bimbingan kelompok dengan tekhnik peer group. Untuk mengetahui validitas instrumen maka peneliti 
menggunakan construct validity. Validitas konstrak (construct validity) merupaan pembuatan instrumen yang didasarkan pada konsep teori yang dipandang kokoh. Setelah pengujian konstrak selesai maka diteruskan dengan uji coba instrumen. Dalam pengujian validitas tiap butir, peneliti menggunakan analisis item, yaitu mengkorelasikan skor tiap butir dengan skor total yang merupakan jumlah tiap skor butir. Syarat minimum untuk dianggap memenuhi syarat adalah kalau $r=0,3$, jadi kalau korelasi antara tiap butir dengan skor total kurang dari 0,3 maka butir dalam instrumen tersebut dinyatakan tidak valid dan rumus yang digunakan adalah rumus Produk Moment. Adapun rumusnya sebagai berikut,

$$
\begin{aligned}
& \text { xy } \\
& \mathrm{r}= \\
& \frac{n \sum x y-\left(\sum_{x}\right)\left(\sum_{y}\right)}{\sqrt{\left\{n \sum_{x^{2}}-\left(\sum_{x}\right)^{2}\right\}\left\{n \sum_{y^{2}}-\left(\sum_{y}\right)^{2}\right\}}} \\
& r^{x y} \quad=\text { Koefisien korelasi antar } \\
& \text { variable } \mathrm{x} \text { dan } \mathrm{y} \\
& \mathrm{x} \quad=\text { Skor butir soal } \\
& \mathrm{y}=\text { Skor total } \\
& \mathrm{x}=\text { Kuadrat skor item } \\
& { }^{2} \quad=\text { Kuadrat skor total } \\
& \text { xy } \quad=\text { Perkalian antara skor butir } \\
& \mathrm{N} \quad=\text { Jumlah subyek }
\end{aligned}
$$

Instrumen dikatakan reliabel apabila mampu menghasilkan ukuran yang relatif tetap. Pengujian reliabilitas dilakukan dengan internal consistency dengan tekhnik belah dua (split half) yang dianalisis dengan rumus Spearman Brown. Untuk hal ini maka butir-butir instrumen di belah menjadi dua kelompok yaitu kelompok instrumen ganjil dan kelompok instrumen genap, selanjutnya skor data tiap kelompok tersebut disusun sendiri. Adapun rumus Spearman Brown, sebagai berikut,

$$
r_{i=\frac{2 \cdot r_{b}}{1+r_{b}}}
$$

Keterangan :

$\mathrm{r}_{\mathrm{i}}=$ reliabilitas internal seluruh instrumen

$\mathrm{r}_{\mathrm{b}}=$ korelasi product moment antara belahan pertama dan kedua

\section{Teknik Analisis Data}

Dalam menguji keefektifan, peneliti menggunakan metode one group pre test post test design, dengan membandingkan antara hasil pre-test dan post-test. Rumus yang digunakan untuk menguji keefektifan produk adalah rumus Wilcoxon, adapun rumus Wilcoxon dapat dilihat dibawah ini,

$$
Z=\frac{T-\left[\frac{1}{4 N(N+1)}\right]}{\sqrt{\frac{1}{24 N(N+1)(2 N+1)}}}
$$

Keterangan : 
Z $=$ Nilai hasil beda

$\mathrm{N}$ = Banyak data yang berubah setelah diberi perlakukan berbeda

$\mathrm{T}=$ Jumlah rangking dari nilai selisih yang negative atau positif

\section{HASIL PENELITIAN DAN PEMBAHASAN}

Berdasarkan dari hasil sebaran skala intesitas belajar, didapatkan angka pree test sebesar 4500 atau $70 \%$. Setelah diberikan perlakukan dengan layanan informasi melalui bimbingan kelompok dengan teknik peer group angka yang didapatkan yaitu 5500 atau $85 \%$. Siswa yang diberikan perlakuan mengalami peningkatan sebesar $14 \%$. Untuk lebih memantapkan tentang ada atau tidaknya peningkatan setelah diberikan perlakuan untuk menguji keefektifan produk maka peneliti menggunakan analisis data uji keefektifan dengan menggunakan rumus wilcoxon.

Dari output terlihat bahwa ada 30 data, dimana 2 data memiliki nilai negatif (selisih pre dan post), 26 data bernilai positif, dan 2 data bernilai sama. Nilai Sum of Ranks atau nilai uji wilcoxon (t-hitung) $=3$. Dengan melihat tabel wilcoxon dengan diperoleh $\mathrm{t}$-tabel $=0,000$

\section{Test Statistics $^{b}$}

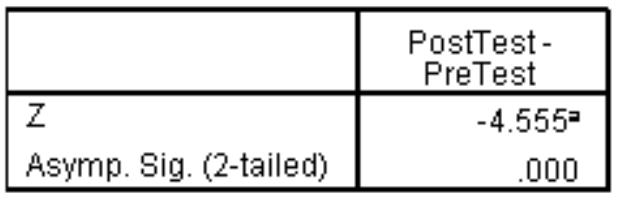

a. Based on negative ranks.

b. Wilcoxon Signed Ranks Test
Terlihat bahwa pada kolom asymp sig (2-tailed) untuk diuji 2 sisi adalah 0,000. Karena kasus adalah uji satu sisi, maka probabilitas menjadi $0,000 / 2=0,000$. Sehingga Maka dapat dilihat bahwa layanan informasi melalui bimbingan kelompok dengan teknik peer group efektif dalam meningkatkan intesitas belajar siswa SD Negeri Tamansari II.

Intensitas sebagai kualitas suatu kondisi atau derajat kualitas, atau kualitas dari suatu pengalaman indera, yaitu ukuran kuantitif tentang kekuatan atau derajat suatu kekuatan. Dalam intensitas belajar kelompok seseorang melakukan suatu tindakan yang akan membuat perubahan pada dirinya maupun orang lain. Tindakan tersebut menggunakan dan memaksimalkan kemampuan yang dimiliki oleh masing-masing individu.

Kemampuan yang dimaksud ialah kemampuan setiap indera dalam diri individu. Sehingga intensitas itu sendiri merupakan derajat kualitas tingkah laku seseorang dalam melakukan suatu tindakan. Dengan demikian berdasarkan pada pengertian belajar kelompok yang telah diuraikan sebelumnya maka intensitas belajar kelompok adalah derajat kualitas dari sekumpulan orang dalam melakukan suatu perubahan yang menyangkut afeksi, psikomotorik dan kognitif melalui pengalaman dan latihan yang relatif bersifat tetap untuk mencapai tujuan bersama. 


\section{KESIMPULAN DAN SARAN \\ Kesimpulan}

Berdasarkan hasil penelitian yang telah peneliti laksanakan bahwa bimbingan kelompok dengan teknik peer group efektif meningkatkan intensitas belajar siswa SD Negeri Tamansari II. Hal ini terbukti dengan asymp sig (2-tailed) untuk diuji 2 sisi adalah 0,000, maka probabilitas menjadi $0,000 / 2=0,000$.

\section{Saran}

Adapun beberapa saran yang dapat dikemukakan berdasarkan kelemahan pelaksanaan layanan bimbingan dan konseling di SD Negeri Tamansari II, sebagai berikut:

1. Guru di SD Negeri Tamansari II hendaknya merencanakan pelaksanan layanan bimbingan dan konseling sehingga bisa terprogram dengan baik.

2. Belajar kelompok sangat penting bagi siswa dalam pelaksanaan belajar karena belajar kelompok bisa meningkatkan prestasi belajar siswa, maka guru di SD Negeri Tamansari II hendaknya memperhatikan hal tersebut.

3. Guru di SD Negeri Tamansari II hendaknya mengembangkan dan memanfaatkan layanan dalam bimbingan dan konseling.

\section{DAFTAR PUSTAKA}

Ahmadi, Abu dan Widodo Supriyono. 2004. Psikologi belajar. Jakarta: Rineka Cipta.
Arikunto, Suharsimi. 2006. Prosedur Penelitian Suatu Pendekatan Praktik. Jakarta: PT. Rineka Cipta.

Arsyad, Azhar. 2010. Media Pembelajaran. Jakarta: Raja Grafindo Persada.

Azwar, Saefudin. 2007. Metodologi Pendidikan. Yogyakarta: Pustaka Pelajar Offset.

Depdiknas. 2003. Undang-Undang No 2 Tahun 2003. Sistem Pendidikan Nasional. Bandung : Citra Umbara.

Djamarah, Syaiful Bahri. 2002. Strategi Belajar Mengajar. Jakarta: Rineka Cipta.

Hamalik, Oemar. 2000. Psikologi Belajar dan Pengajaran. Bandung: Sinar Baru Algensindo.

(2009). Psikologi Belajar dan Mengajar. Bandung: PT Sinar Baru Algensindo.

Kartini, Kartono. 2000. Kamus Psikologi. Bandung: CV Pionir Jaya.

Mustaqim. 2008. Psikologi Pendidikan. Semarang: Pustaka Belajar.

Natawidjaja, R. 2009. Konseling Kelompok : Konsep Dasar dan Pendekatan. Bandung : Rizqi.

Nurihsan, Juntika A. 2006. Bimbingan dan Konseling. Bandung: Refika Aditama. 
Prayitno. 2001. Panduan Kegiatan Pengawasan Bimbingan dan Konseling. Jakarta: Rineka Cipta.

Prayitno. 2004. Layanan Bimbingan Kelompok Dan Konseling Kelompok. Padang: Universitas Negeri Padang.

. 1998. Seri Pemandu Pelaksanaan Bimbingan dan Konseling di Sekolah. Jakarta: PT. Ikrar Mandiriabadi.

Romlah, T. 2001. Teori dan Praktek Bimbingan Kelompok. Malang: Universitas Negeri Malang.
Salahudin, A. 2012. Bimbingan dan Konseling. Bandung: Pustaka Setia.

Santoso, Slamet. 2006. Dinamika Kelompok. Jakarta: Bumi Aksara.

Soemanto, Wasty. 2006. Psikologi Pendidikan. Jakarta: Rineka Cipta. 